\title{
Performance of Cement-Based Patch Repair Materials in Plain and Reinforced Concrete Members
}

\author{
A.H. Al-Saidy ${ }^{*}$ \\ Department of Civil \& Architectural Engineering, College of Engineering, Sultan Qaboos University, Oman
}

Received 2 March 2015; Accepted 12 April 2016

\begin{abstract}
Structural elements such as beams, slabs, and columns may require strengthening or repair during their service life. Different repair materials (RMs) are available and it is usually difficult to choose the best ones, especially when considering the cost of such materials. This paper presents the results of an experimental investigation of patch RMs on plain concrete prisms as well as on reinforced concrete beams. Three cement-based RMs available in the market with different mechanical properties and an ordinary Portland cement (OPC) mix produced in the lab were used in the study. Damage was induced in prisms/beams and then repaired using different materials. The experimental work included assessment of the flexural strength of damaged/repaired plain concrete prisms; slant shear (bond) strength between the concrete and the RM; axial strength of damaged/repaired plain concrete prisms and bond of the repair materials in damaged/repaired reinforced concrete beams loaded to failure. The test results showed that all RMs performed well in restoring the strength of damaged plain concrete. Compatibility of the RMs with substrate concrete was found to be more important in the behavior than superior mechanical properties of the RMs. No difference was noted in the behavior between the RMs in repairing reinforced concrete beams at the tension side.
\end{abstract}

Keywords: Patch repair, Repair materials, Rehabilitation, Retrofitting.

$$
\text { أداء المواد الإسمنتية ِِّ الإصلاح الجزئي لعناصر المنشآت الخرسـانية العادية والمسلحة }
$$

الملخص: العناصر الإنشائية كالجسور والألواح والأعمدة قد تتطلب تعزيز أو إصلاح خلال فترة مدة خدمتها. ويوجد حاليًا العديد من المواد الإصلاحية المتاحة وعادة ما يكون من الصعب المفاضلة بينها لاختيار الأفضل، خصوصا عند النظر ِّ تقاوت كلفة هذه المواد. تقدم هذه الدراسـة نتائج التجارب العملية لفحص أداء مواد الإصلاح بشكل جزئي لجسور قصيرة من الخرسانة العادية وجسور من الخرسانة المسلحة. وِّهذه الدراسة تم اختيار ثلاثة أنواع من مواد إصلاح الخرسانة المتوفرة وِّ السوق بخصائص ميكانيكية مختلفة بالإضافة الى مزيج الإسهنت البورتلاندي العادي الذي تم تصنيعه بِّ المختبر. بداية تم إحداث تلف متعمد يُّ جميع الجسور ومن ثم إصلاحها باستخدام مواد إصلاحية مختلفة. واشتملت التجارب العملية على وملى إختبار مقاومة الثني يخ الجسور، قوة الإلتصاق بين الخرسـانة ومادة الإصلاح لعينات إسطوانية، وقوة التحمل المحورية لأعمدة قصيرة. ولفرض المقارنة تم إختبار عينات سليمة وعينات متضررة بدون إصلاح وعينات متضررة تم إصلاحها قبل الفحص. وقد أظهرت نتائج الاختبار أن جميع المواد المستخدمة كان أداؤها جيدا ِِّ إستعادة الجسور القصيرة لقدرتها ومقاومتها

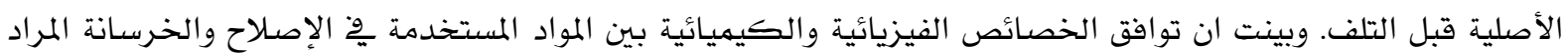
إصلاحها أكثر أثرا وأهمية ِوْ كفاءة الأداء من الخصائص الميكانيكية الفائقة التي تتمتع بها المادة المستخدمة. كذلك

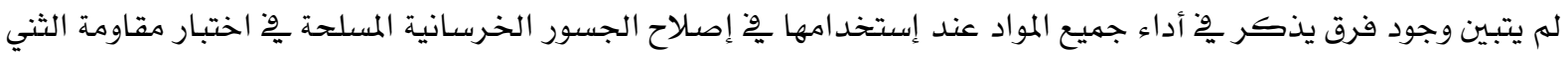
وِّ2 الجانب المعرض للشد.

الكلمات المفتاحية: الإصلاح الجزئي، المواد الإصلاحية، تأهيل المنشآت، ادخال الإصلاحات

* Corresponding author's email: alsaidy@squ.edu.om 


\section{Introduction}

Repair and rehabilitation of reinforced concrete structures are common requirements in modern construction. Structural elements such as beams, slabs, and columns may require strengthening or repair during their service life due to aging, increased loads, and deterioration caused by the surrounding harsh environment. Steel corrosion is a major cause of deterioration which disrupts the cover zone of reinforced concrete. The conventional approach to repair a corroded reinforced concrete member is the use of patches to repair in the zones where cracking and spalling take place. Repairs are generally undertaken by removing the damaged concrete beyond the steel reinforcement, and reinforcements are then cleaned in cases of minor corrosion or replaced if severely damaged. Finally, a prepackaged cementitious repair material $(\mathrm{RM})$ is applied.

Many types of RMs are available commercially, and the selection for reinstating a deteriorated concrete structure is usually done on a relatively ad hoc basis. The repair and rehabilitation of reinforced concrete structures can only be successful if the new materials interact effectively with the parent concrete and form a durable barrier against the ingress of carbon dioxide and chlorides. Problems may arise whenever a dimensionally unstable RM is placed against an aged (and, therefore, dimensionally stable) substrate concrete.

Several materials are available in the market for the repair of deteriorated concrete structures. Such RMs are classified, for example, as cement, epoxy resins, polymer latex, polyester resins, and polyvinyl acetate, with cement-based and epoxy-based RMs being the two most widely used. However, manufacturers are reluctant to provide complete details of their materials, which makes the selection of appropriate RMs difficult. Potential users are faced with a wide choice of materials and little guidance on their properties and long-term performance (Cabrera and Al-Hasan 1997).

The design of patch repair is usually based on the experience of specialist contractors, and selection of RMs is made based on their relative short-term properties such as strength, bond, and early age plastic shrinkage. Although these properties indicate the immediate performance of the repair, they give little information on its long-term performance with respect to cracking and composite action with the substrate concrete to carry loads and prevent deformations. Numerous studies in the literature deal with the evaluation of different RMs. A great deal of the research has focused on durability issues associated with RMs such as chloride permeability, electrical resistivity, and carbonation (Al-Zahrani et al. 2003; Mangat and Limbachiya 1995; Ueda et al. 2011). Such studies have concluded that there is no clear difference between the cement- and polymerbased repair mortars with regard to the chloride permeability. However, carbonation has been identified as an issue in cement- and polymerbased repair mortars except in dense mortars which has been attributed to the addition of silica fume, fibers, and/or other additives. Other studies have focused on the properties that affect the stability of RMs such as shrinkage, thermal properties, and modulus of elasticity (Mangat and Limbachiya 1997; Margan 1996). Polymer-based repair mortars have been found to have lower shrinkage strains compared to cement-based repair mortar. Compatibility of the modulus of the elasticity of RM with that of the substrate concrete were found to have a great influence on load sharing or the contribution of RMs in resisting the applied load of the repaired member. RMs with a modulus of elasticity close to that of the substrate concrete tends to provide a stable repair under applied loads.

The efficiency and durability of a repaired system depends on the bond between the concrete substrate and RM. By increasing the surface roughness, the surface treatment of concrete substrate can promote mechanical interlocking, which is one of the basic mechanisms of adhesion. The durability of a bond depends on several factors, each acting with different degrees of influence. The five major factors as reported by researchers in the literature are micro cracking, the absence of a laitance layer, cleanliness before an overlay placement, and compaction and curing procedures. The first three parameters are directly related to substrate characteristics, which can be modified by surface treatment. The treatment of a concrete substrate is commonly used for cleaning, removing the laitance layer, and roughening the surface. However, it can induce micro cracking if it is not well operated with regard to the quality and strength of concrete (Courard et al. 2006; Courard et al. 2014; Garbacz et al. 2005; Liu et al. 2014; Qian et al. 2014).

The performance of the RMs in service under structural loading has received relatively little 
attention from the research community, especially in the case of patch repairs. Some studies have considered the behavior of repaired reinforced concrete members under service loads (Abu-Tair 1997; AlFarabi et al. 2006; Ghassan and Zai-UL-Hasan 1999; Rio et al. 2005). However, there is no agreement between researches regarding the properties, which should be considered in the evaluation. This lack of agreement can have serious effects where differences in mechanical properties can lead to short- or long-term performance or durability problems.

This paper presents the results of three commercially available RMs on the Omani market and one laboratory-prepared material. The experimental work presented here includes bond strength; flexural and axial strength of damaged/repaired prisms; bond and strength behavior of damaged/repaired reinforced concrete beams.

\section{Repair Materials}

Four RMs were used in this study. A brief description of each of these materials follows.

\subsection{Repair Materials (RM1, RM2, and RM3)}

The three RMs were pre-packed commercial cement-based materials supplied as ready-touse dry powders which require only the addition of clean water to produce a highly consistent, lightweight repair mortar suitable for general purpose concrete and masonry repairs. Each material is packaged in $20 \mathrm{~kg}$ bags. To get the required mix, water at a measurement of $15-18 \%$ of the powder weight was added according to the manufacturer's instructions. However, the difference between the three materials is mainly in the mechanical properties (Table 1).

Table 1. Properties of the repair materials after 28 days.

\begin{tabular}{lcccc}
\hline $\begin{array}{c}\text { Repair } \\
\text { Material }\end{array}$ & $\begin{array}{c}f_{c} \\
\text { (Mpa) }\end{array}$ & $\begin{array}{c}f_{t} \\
\text { (Mpa) }\end{array}$ & $\begin{array}{c}E \\
\text { (Gpa) }\end{array}$ & $\begin{array}{c}f_{r} \\
\text { (Mpa) }\end{array}$ \\
\hline RM1 & 54.3 & 4.4 & 31.7 & 7.8 \\
RM2 & 52.5 & 4.3 & 31.1 & 8.1 \\
RM3 & 63.7 & 4.2 & 34.4 & 7.8 \\
OPC & 51.2 & 4.2 & 30.0 & 7.7 \\
\hline
\end{tabular}

$f_{c}=$ Cube compressive strength

$f_{t}=$ Cylinder tensile strength

$E=$ Modulus of elasticity

$f_{r}=$ Prism flexural strength

\subsection{Ordinary Portland Cement (OPC)}

This RM was obtained by mixing OPC with water at a ratio of $\mathrm{w} / \mathrm{c}$ of 0.25 . OPC was chosen in order to have a consistency similar to that of the other RMs.

\subsection{Mechanical Properties}

a) Compressive and tensile strength according to American Society for Testing and Materials (ASTM) standard C109.

b) Flexural strength according to ASTM standard C78.

c) Elastic modulus according to ASTM standard C469.

\section{Specimen Details}

To evaluate the performance of each RM under service load, four different tests were carried out. The bond of the RM to the substrate concrete was evaluated through the slant shear test. Behavior of the RM applied to plain concrete was evaluated using damaged/repaired prisms tested in flexure and axial compression. To simulate the behavior of a real field situation, reinforced concrete beams were damaged and then patch-repaired using each of the RMs. The reinforced concrete beams were tested to failure to observe the bond of the RM through all loading stages.

\subsection{Slant Shear Specimens}

The bond strength test (slant shear test) was done according to ASTM standard C882 using 75 x $150 \mathrm{~mm}$ concrete cylinders. Each cylinder was cut as specified in the standard at $30^{\circ}$ by a concrete cutting machine after curing for 28 days (Fig. 1a). After cutting these cylinders, each piece was replaced in a cylindrical mold to cast the RM above it. Three specimens were used for each RM. Figure $1 \mathrm{~b}$ shows the combined specimen after casting the RM.

\subsection{Damaged/Repaired Prisms}

To test the flexural strength, six $100 \times 100 \times$ $500 \mathrm{~mm}$ prisms were made from each mix or RM. Two prisms were undamaged, two were damaged, and the other two were damaged but then repaired with the RMs (damaged /repaired). A similar number of prisms were also made to test the axial strength: two undamaged, two damaged, and two damaged/repaired. In order to produce the same damage in all specimens, a preformed mold was used while casting the prisms to 


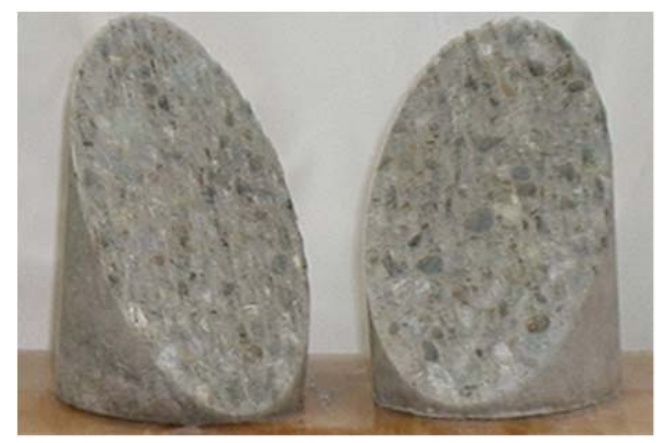

(a)

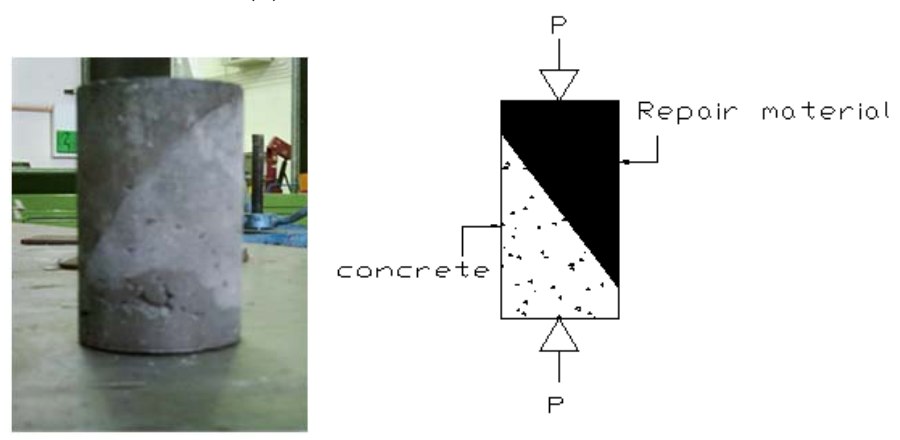

(b)

Figure 1. Slant Shear Test: (a) Concrete cylinder after cutting, and (b) Combined cylinder of repair material and concrete substrate.

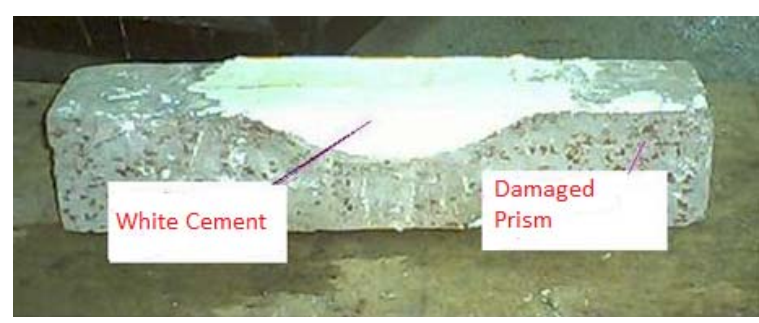

a) Casting of white cement in damaged area.

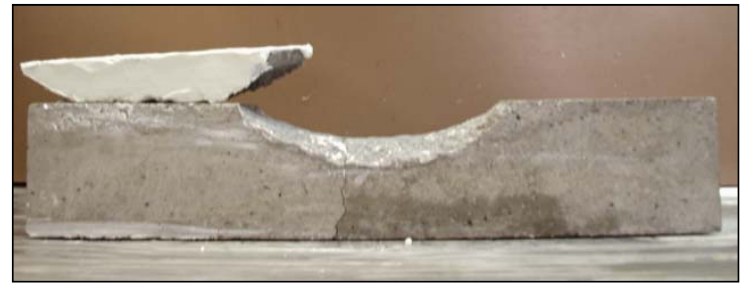

b) Removing the white cement patch.

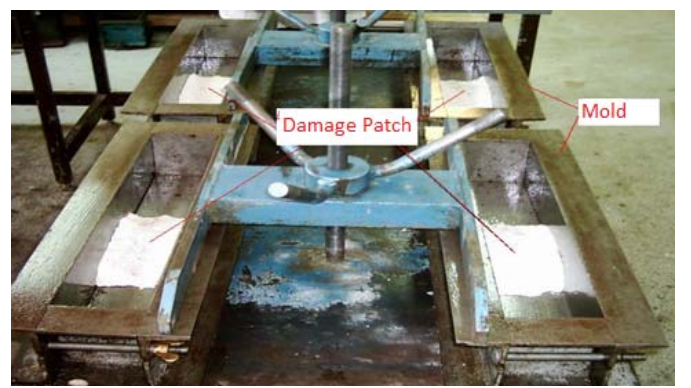

c) Placing the white cement patch in the prism molds before casting.

Figure 2. Preparation of damage mold to induce uniform damage in prisms. 
create a damaged section measuring $200 \mathrm{~mm}$ in length with a maximum depth of $25 \mathrm{~mm}$ within the middle third of the prism (Fig. 2). To accomplish this specific type of damage, a concrete prism was damaged by chipping the concrete with $200 \mathrm{~mm}$ width and a maximum depth of $25 \mathrm{~mm}$. To simulate the actual damage in concrete, the damage made by chipping the concrete was not uniform. After chipping, the damaged area was patched with white cement mortar. Once the white cement patch had set, it was removed from the concrete with all of the rough surfaces imprinted on the surface of the patch. The patch was then placed in the prism mold before casting (Fig. 2(c)). After casting, this patch was removed from the prism, creating the required damage. The same procedure was repeated with the other specimens. In this way, the damage in all specimens was uniform in order to make a fair comparison between all RMs.

\subsection{Damaged/Repaired Reinforced Concrete Beams}

In order to study the behavior of reinforced concrete elements, six reinforced concrete beams were cast in the laboratory (Table 2). The beams consisted of one undamaged beam, one damaged beam, and four damaged/repaired beams. The beams were reinforced for tension at their bottom sides using two bars, each $10 \mathrm{~mm}$ in diameter. Each beam was 2,700 $\mathrm{mm}$ long with a cross-section of $100 \times 150 \mathrm{~mm}$ and a cover of $25 \mathrm{~mm}$. For the damaged and repaired beams, the damage was induced during casting with approximately the same shape and size by the same procedure described in Section 3.2 for prism preparation. The damage zone was 400 $\mathrm{mm}$ long and $40 \mathrm{~mm}$ deep $(25 \mathrm{~mm}$ cover +10 $\mathrm{mm}$ bar diameter $+5 \mathrm{~mm}$ above the

Table 2. Description of Beams.

\begin{tabular}{ll}
\hline Beam & \multicolumn{1}{c}{ Description } \\
\hline C & Control beam without damage \\
D & Damaged beam \\
DRM1 & $\begin{array}{l}\text { Damaged and batch repaired using } \\
\text { RM1 }\end{array}$ \\
DRM2 & Damaged and batch repaired using \\
& RM2 \\
DRM3 & Damaged and batch repaired using \\
& RM3 \\
DRM4 & $\begin{array}{l}\text { Damaged and batch repaired using } \\
\text { OPC }\end{array}$ \\
\hline
\end{tabular}

reinforcement) at the middle of the beam. After casting, each beam was cured for 28 days using polythene sheets. Four of the damaged beams were repaired using the selected RMs and were cured for an additional seven days prior to testing.

\section{Test Setup}

All specimens were tested after curing using a wet Hessian cloth for 35 days (28 days for concrete substrate + seven days for RM). A bond strength test (slant shear test) was done according to the ASTM Standard C882. Each cylinder of the combined material (concrete + RM) was placed under the compression machine, and the failure load was recorded. The flexural strength of the undamaged, damaged, and damaged/repaired plain concrete prisms was measured according to ASTM Standard C78. Each prism was loaded under four-point bending; the failure load was recorded and the location of the failure was observed.

In addition to flexural strength, a compressive strength test was done on the plain concrete prisms. Six prisms were tested for each RM: two undamaged, two damaged, and two damaged/repaired prisms. The failure load was recorded for each prism, and the compressive strength was calculated. Figure 3 shows the test setup of plain concrete prisms under axial compression.

The reinforced concrete beams were simply supported and subjected to four-point bending (Fig. 4). The beams were supported over 2,400 $\mathrm{mm}$. Linear variable differential transducers (LVDTs) were used to measure deflection at the mid-span of the beam. All beams were loaded at a rate of $0.06 \mathrm{kN} / \mathrm{s}$ until the failure load was reached.

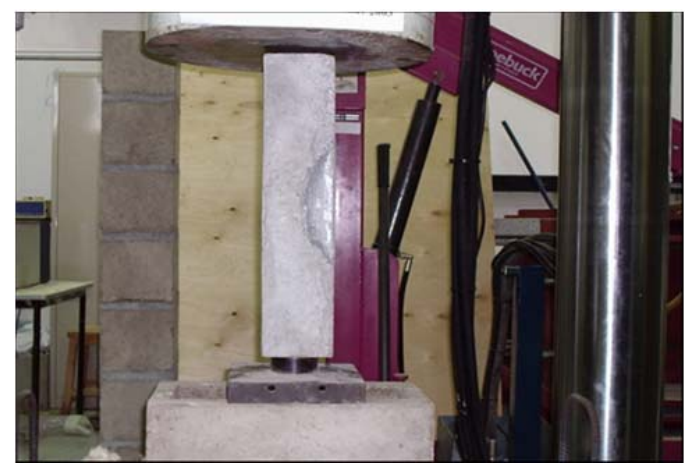

Figure 3. Test setup of plain concrete prisms under axial compression. 

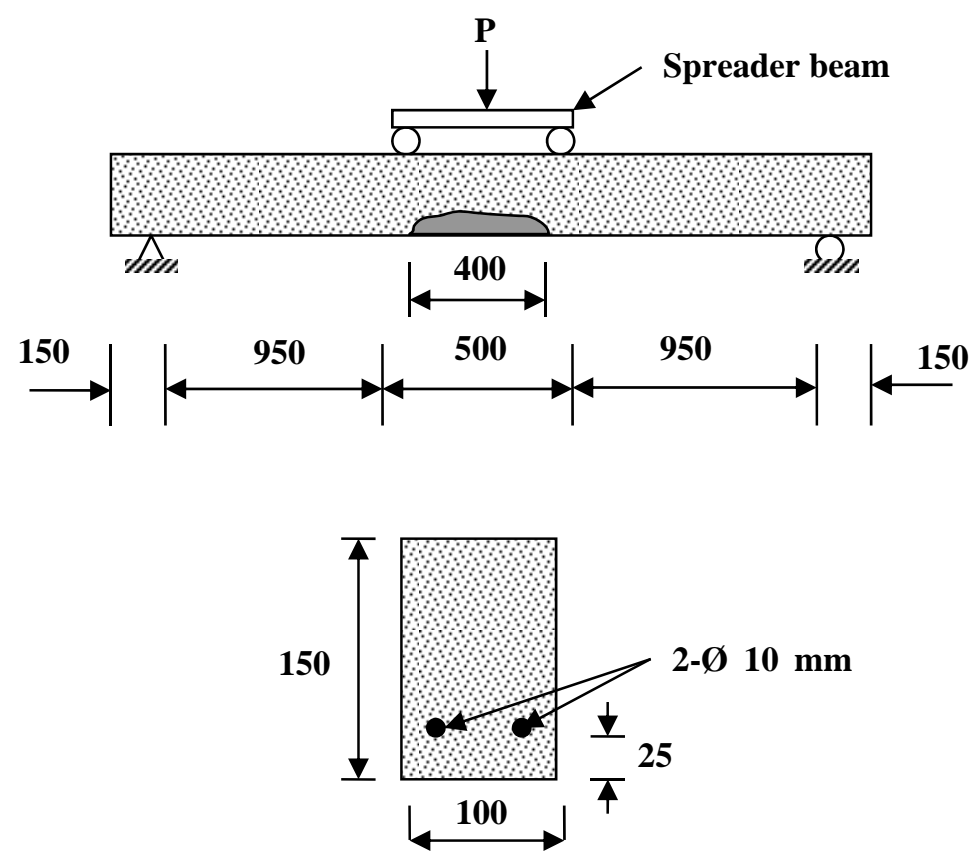

Figure 4. Test setup of reinforced concrete beams.

\section{Test Results and Discussion}

\subsection{Bond Test}

The specimens were loaded axially in compression, which caused failure along the line where the two layers are jointed (Fig. 1). Bond strength was calculated by dividing the failure load by the interface area (ellipse area). The average bond strength (using three specimens) in $\mathrm{N} / \mathrm{mm}^{2}$ were $3.81,4.97,5.78$, and 4.05 for RM1, RM2, RM3, and OPC, respectively. As can be observed, the maximum bond strength was $5.78 \mathrm{~N} / \mathrm{mm}^{2}$ for RM3, whereas the minimum bond strength value was $3.81 \mathrm{~N} / \mathrm{mm}^{2}$ for RM1. There was not much difference between RM1 $\left(3.81 \mathrm{~N} / \mathrm{mm}^{2}\right)$ and the control RM OPC $\left(4.05 \mathrm{~N} / \mathrm{mm}^{2}\right)$. The mode of failure was almost the same for RM1, RM2, and RM3, and failure occurred at the interface surface between the two materials (Fig. 5(a)). Failure of the OPC specimen was due to crushing failure (Fig. 5(b)).

\subsection{Flexural Strength of Damaged/Repaired Plain Concrete Prisms}

The mechanical properties of the concrete substrate which received the RMs are shown in
Table 3. These are the properties of the concrete used in the prisms that later were repaired using each of the four RMs. It should be noted that the flexural strength was assessed for an undamaged concrete prism. Each result was an average of three specimens.

A summary of the results of the flexural strength of the undamaged, damaged, damaged/repaired prisms is shown in Fig. 6. Here the failure load which caused the prism to

Table 3. Properties of concrete substrate of prisms after 28 days.

\begin{tabular}{|c|c|c|c|c|}
\hline Prism & $\begin{array}{c}f_{c} \\
(M p a)\end{array}$ & $\begin{array}{c}f_{t} \\
(M p a)\end{array}$ & $\begin{array}{c}E \\
(G p a)\end{array}$ & $\begin{array}{r}f_{r} \\
(M p a)\end{array}$ \\
\hline $\begin{array}{l}\text { Used with } \\
\text { RM1 }\end{array}$ & 36.2 & 2.6 & 25.3 & 6.9 \\
\hline $\begin{array}{l}\text { Used with } \\
\text { RM2 }\end{array}$ & 35.4 & 3.1 & 24.5 & 7.0 \\
\hline $\begin{array}{l}\text { Used with } \\
\text { RM3 }\end{array}$ & 34.1 & 2.5 & 24.1 & 6.2 \\
\hline $\begin{array}{l}\text { Used with } \\
\text { OPC }\end{array}$ & 37.4 & 2.6 & 26.0 & 6.8 \\
\hline
\end{tabular}




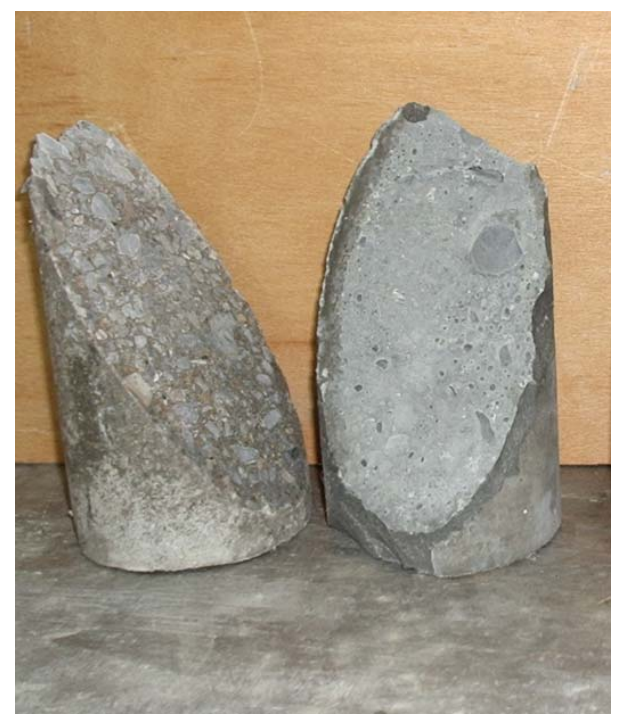

a) Bond failure of RM1, RM2 and RM3

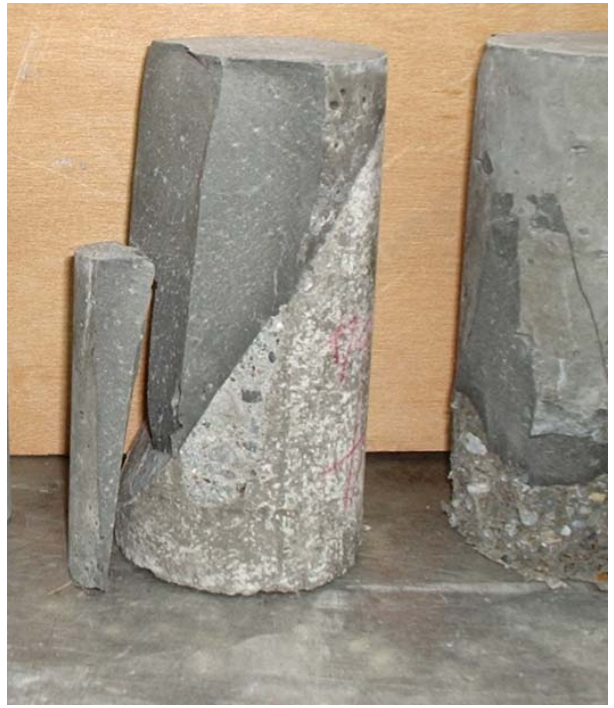

b) Crushing failure of OPC

Figure 5. Modes of failure of the specimens observed during Slant Shear Bond test.

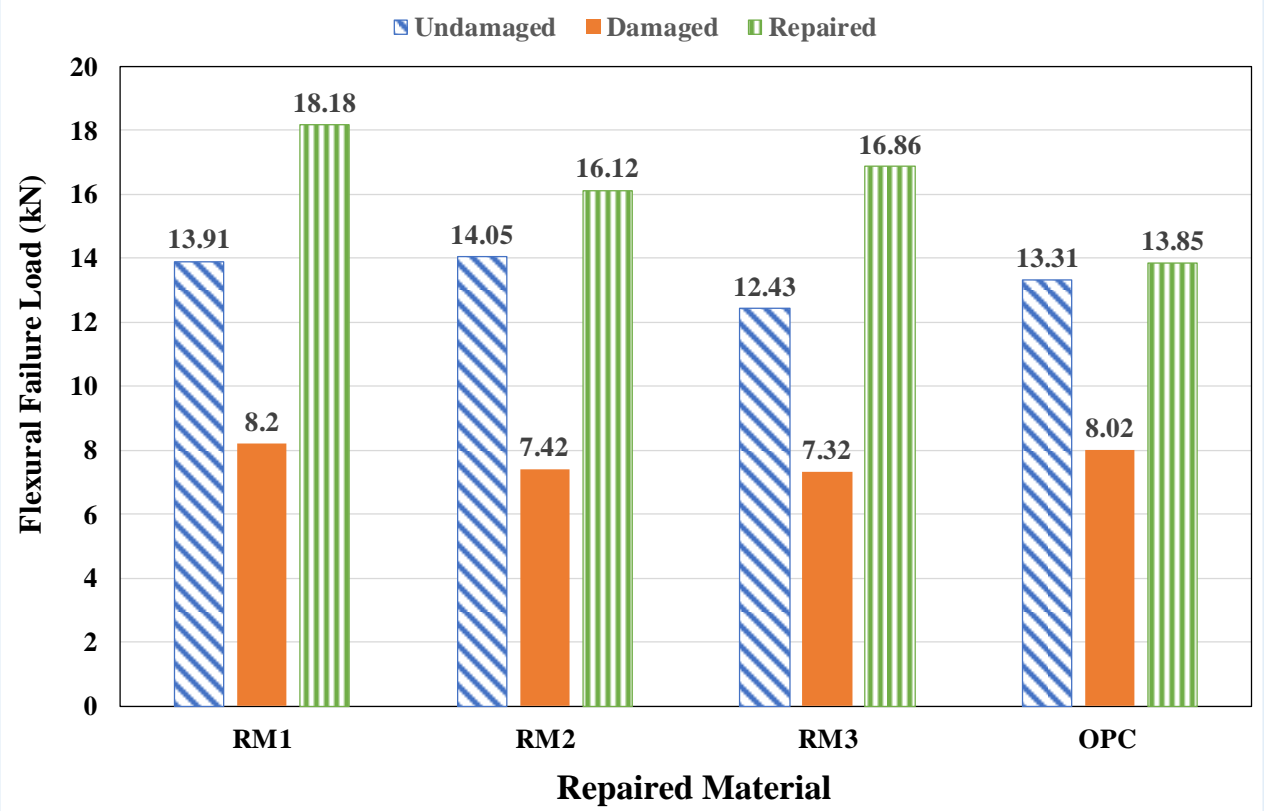

Figure 6. Flexural strength of prisms.

break was reported instead of the flexural stress or modulus of rupture, since the latter might be misleading in the case of damaged prisms where the cross-sectional area was reduced as a result of the damage. It can be seen that the damage caused large reduction in the flexural strength by $45 \%$ of the undamaged prism. However, all repaired prisms failed at a higher load than that of the undamaged prisms. An increase in the failure load of $30 \%, 14 \%, 36 \%$, and $5 \%$ were observed in prism repaired using RM1, RM2, RM3, and OPC, respectively. This clearly shows that the RMs are very effective when loaded under tension. In all prisms, no debonding failure was observed. The location of the cracks and the failure lines of the prisms are shown in Fig. 7. RM1 and RM3 were so strong that the concrete cracked just at the end of the patch where the substrate concrete was weaker in tension than the RM (Fig. 8).

\subsection{Compressive Strength of Damaged/ Repaired Plain Concrete Prism}

This group of prisms had the same damage as the ones that were tested under flexure and 


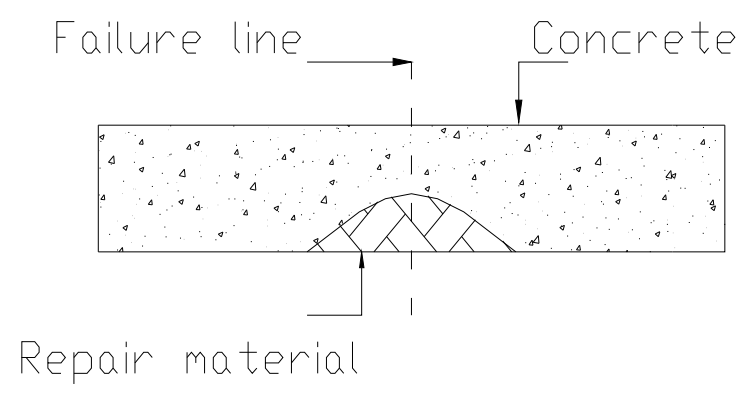

a) Failure mode of RM2, and OPC

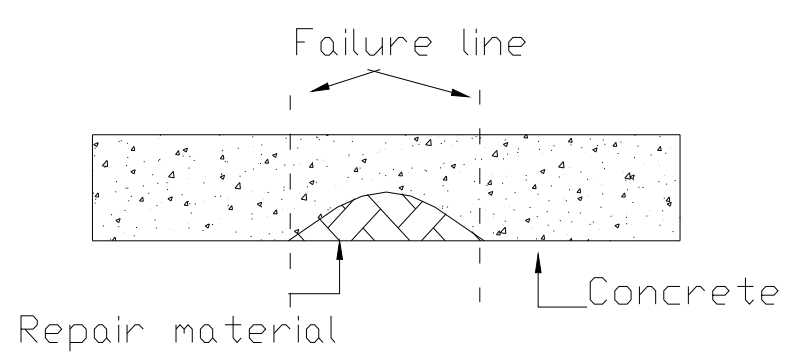

b) Failure mode of RM1 and RM3

Figure 7. Schematic of failure modes in damaged/repaired prisms.

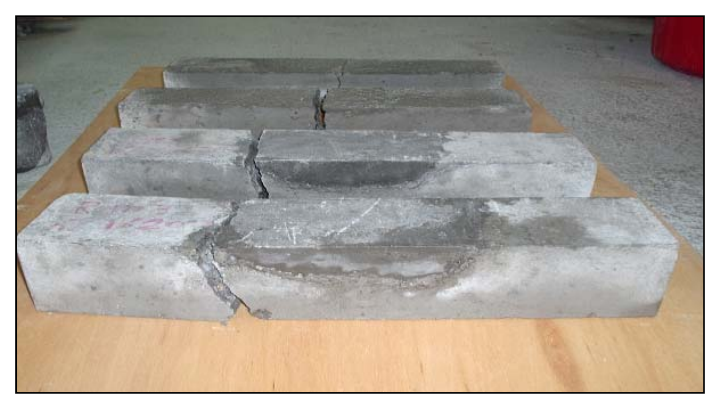

(a) RM1

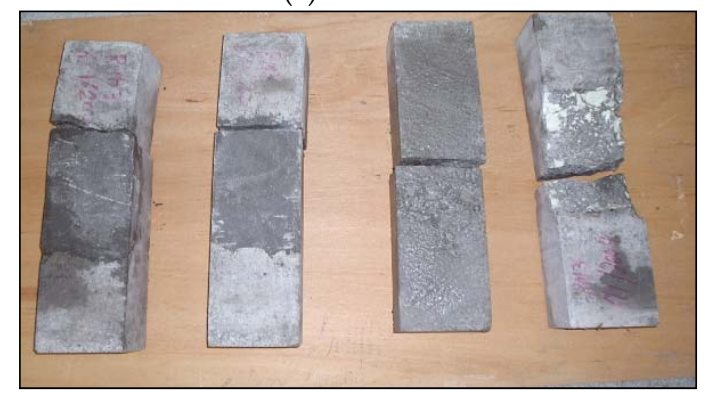

(c) RM3

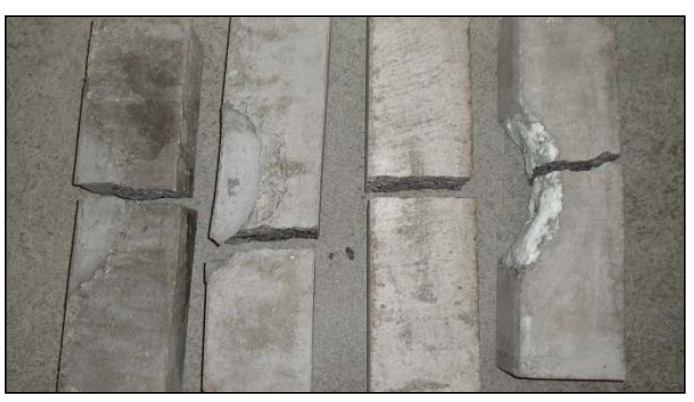

(b) RM2

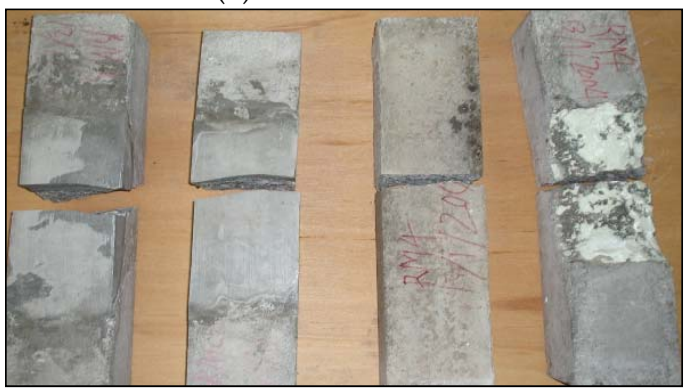

(d) OPC

Figure 8. Modes of failure observed during flexural test of prisms for all repaired materials.

repaired similarly; however, they were tested under axial compression. A summary of the results of the compressive strength of the undamaged, damaged, damaged/repaired prisms is shown in Fig. 9. As expected, all damaged prisms failed at a lower load than the undamaged and repaired prisms due to the reduced cross-sectional area caused by the damage. However, all damaged/repaired prisms showed equal or higher failure loads compared to the undamaged prisms, indicating that the RM contributed to the axial load carrying capacity of the damaged/repaired prisms. 


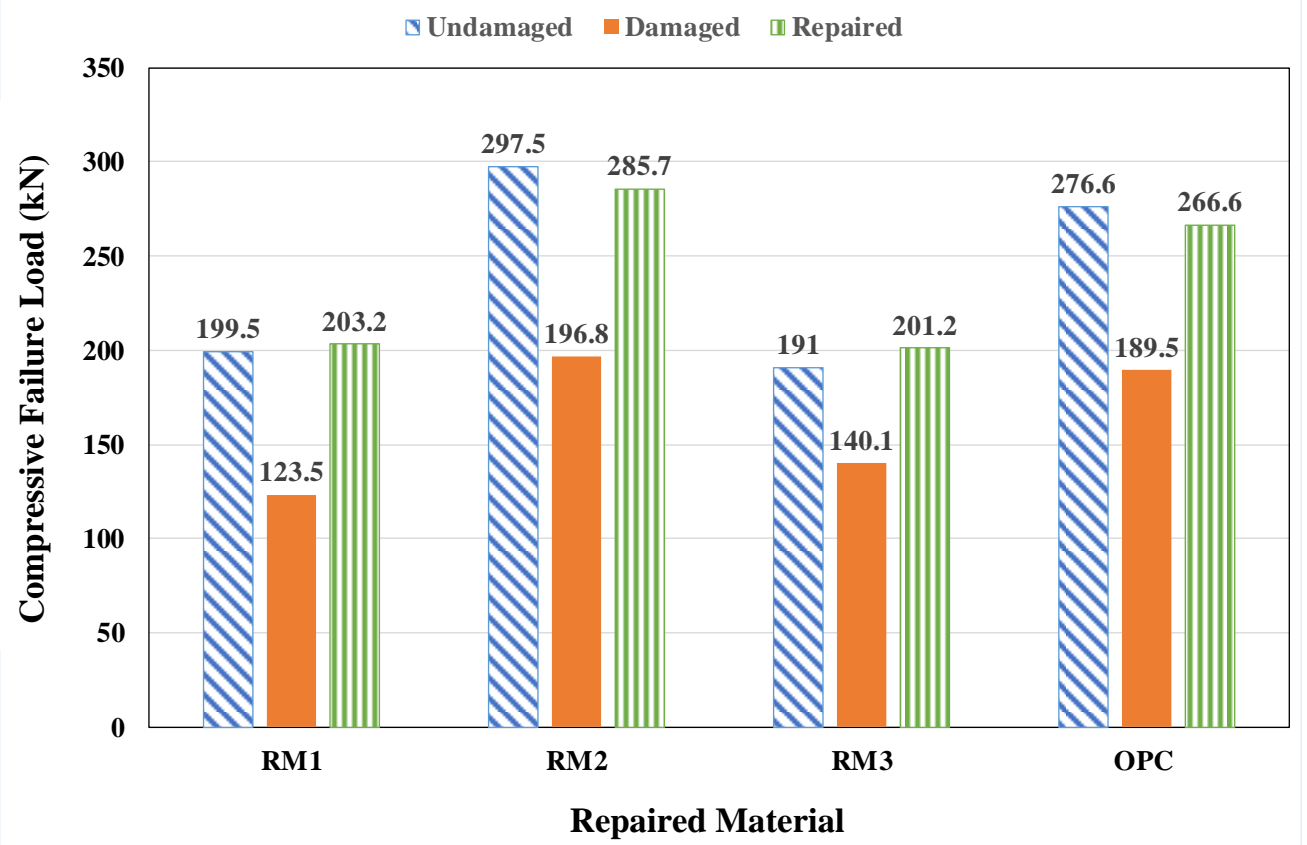

Figure 9. Compressive strength of prisms.

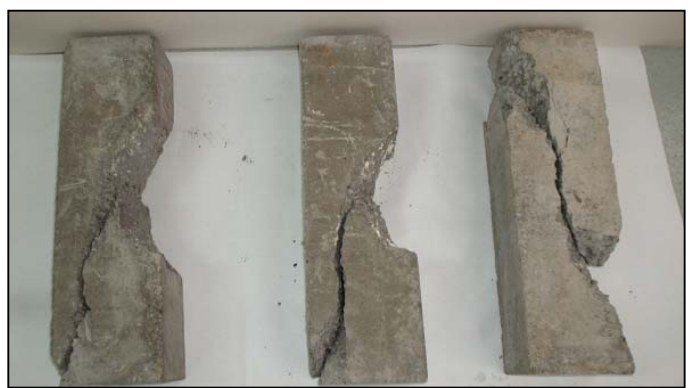

(a) RM1

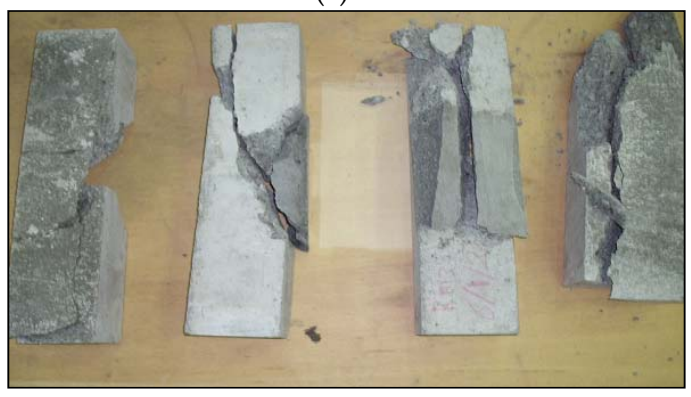

(c) RM3

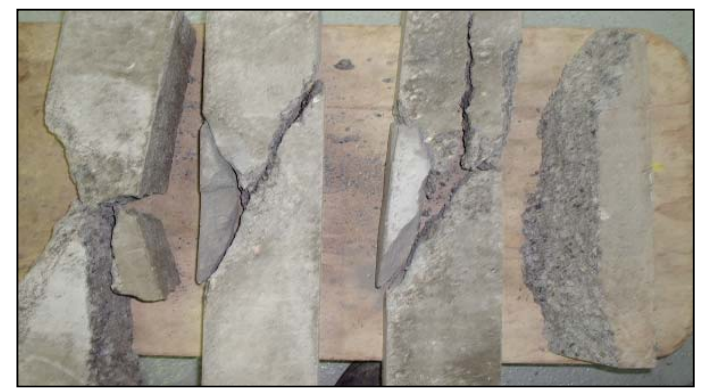

(b) RM2

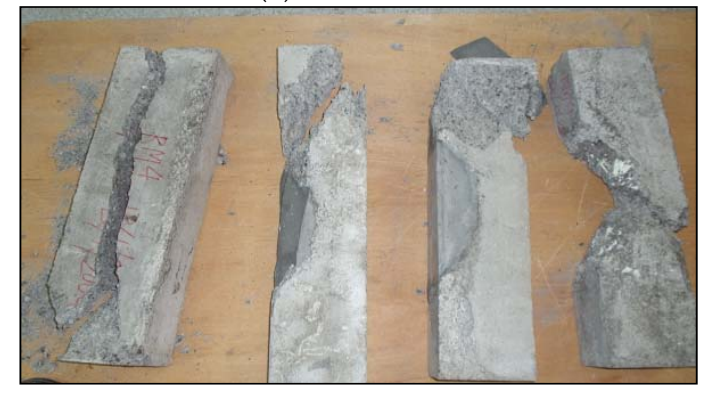

(d) OPC

Figure 10. Modes of failure observed during compressive test for all repaired materials.

In the compressive strength test, the specimens repaired with OPC failed due to compression without detachment of the repair material from their locations, while, the other specimens repaired with RM1, RM2 and RM3 failed due to shear because the RMs detached from their locations as indicated by the inclined failure line in Fig. 10. The OPC RM showed better bond behavior under compression which was also observed in the slant bond test discussed in Section 5.1 .

\subsection{Repaired Reinforced Concrete Beams}

Unlike plain concrete, which is very brittle, reinforced concrete behaves in a ductile manner. Therefore, it was possible to observe the behavior of the combination of repair + concrete in all loading stages as encountered in the field. Load versus mid-span deflections are compared in Fig. 11, showing the undamaged, damaged, and damaged/repaired beams. From Fig. 11, it can be observed that all of the repaired beams resisted an ultimate load slightly higher than the undamaged beam. All beams failed in a 


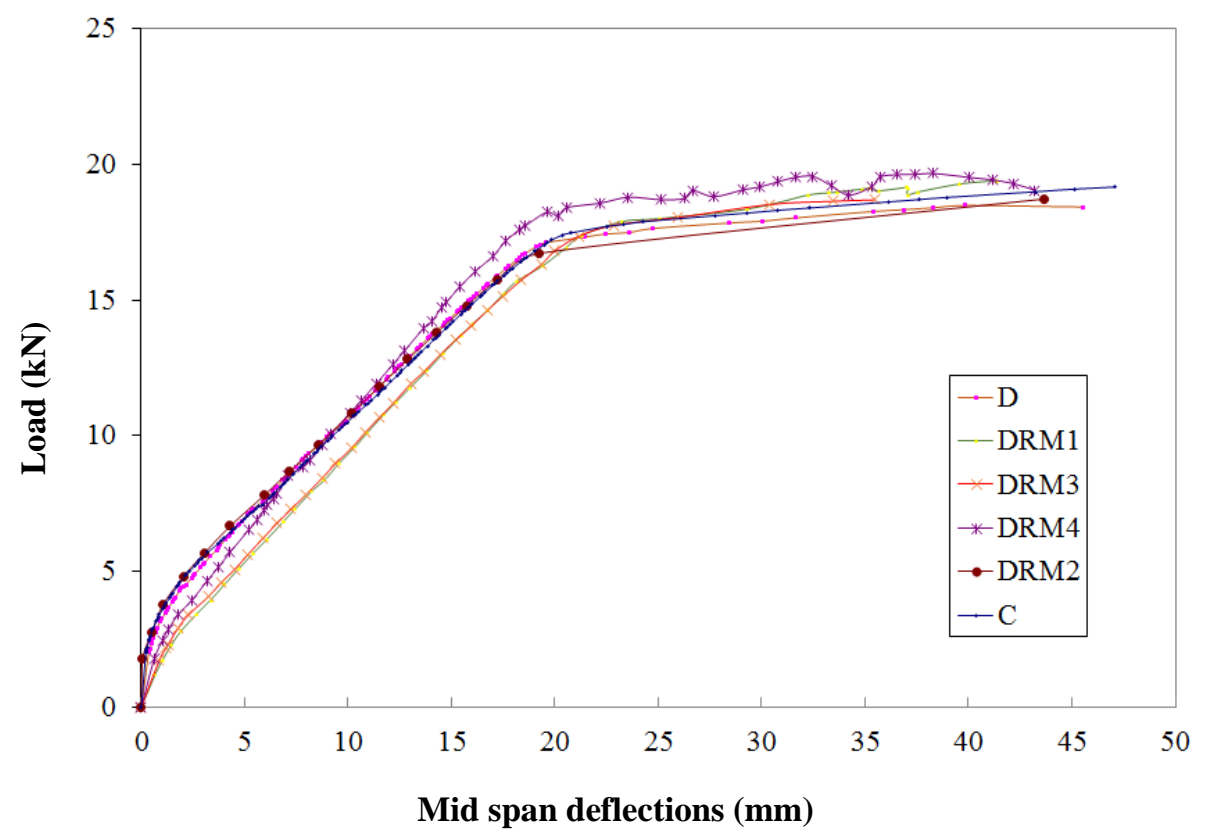

Figure 11. Load vs. mid span deflection of undamaged, damaged, and damaged/repaired beams.

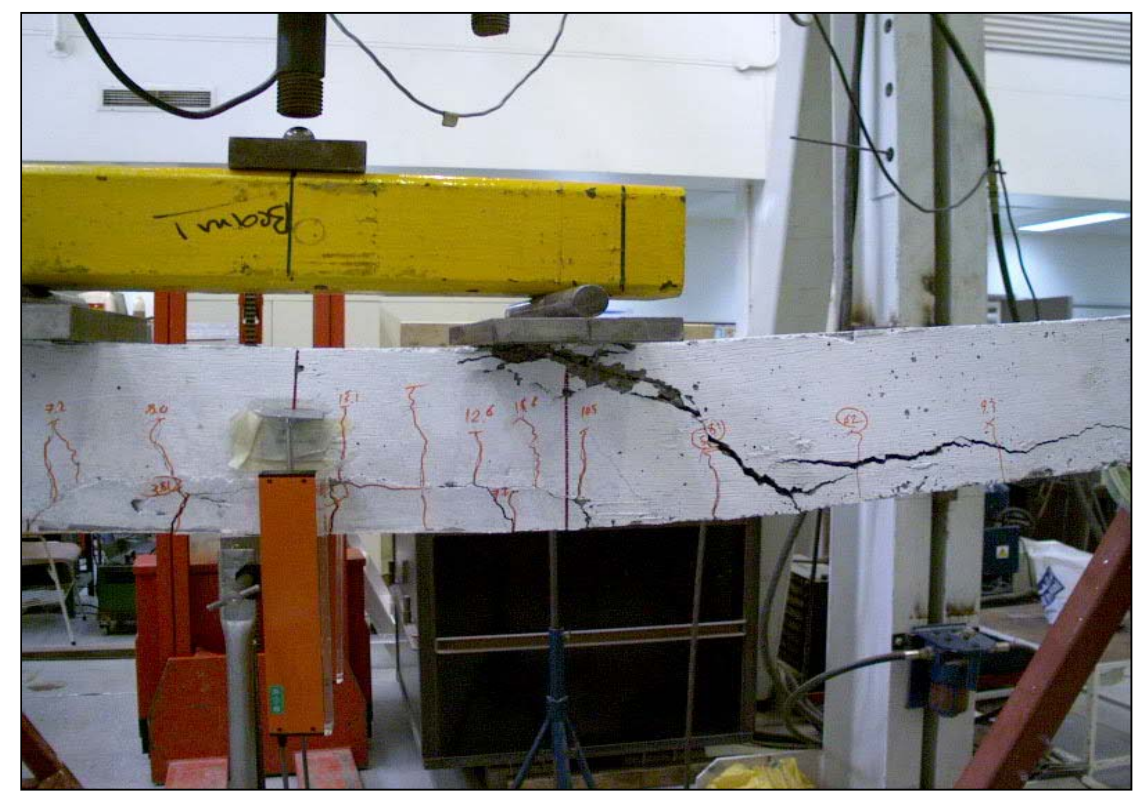

Figure 12. Repaired beam after failure.

ductile manner as in the case of under reinforced concrete beams. Failure occurred as the steel yielded, and ultimately the concrete was crushed in the compression zone. All beams showed similar behaviors until failure as expected. However, the objective was to observe the behavior of the patch RM under all loading stages, including in the inelastic (postyielding) stage.

A summary of the results is shown in Table 4. In all beams, the first cracks appeared in the concrete substrate and then in the RM. In beam
DRM1, the cracks first appeared in concrete at $3.3 \mathrm{kN}$ whereas in the RM the cracks appeared at $5.6 \mathrm{kN}$; the other repaired beams also followed the same pattern (Table 4). The variations in crack appearance can be attributed to the difference in the tensile strength as the RMs have higher tensile strength than the concrete substrate. In all beams, the RMs remained attached to the concrete until the beam failed (Figs. 12 and 13), and no major difference was observed among the repairs made with different materials. 
Table 4. Summary of test results of repaired reinforced beams.

\begin{tabular}{lcccc}
\hline Beam & $\begin{array}{c}\text { Load for first } \\
\text { crack in } \\
\text { concrete (kN) }\end{array}$ & $\begin{array}{c}\text { Load for first } \\
\text { crack in repair } \\
\text { material (kN) }\end{array}$ & $\begin{array}{c}\text { Maximum } \\
\text { Load (kN) }\end{array}$ & $\begin{array}{c}\text { Maximum } \\
\text { Deflection (mm) }\end{array}$ \\
\hline C & - & - & 19.2 & 47.0 \\
D & - & - & 18.5 & 45.0 \\
DRM1 & 3.3 & 5.6 & 19.4 & 41.0 \\
DRM2 & 4.0 & 6.2 & 19.3 & 44.0 \\
DRM3 & 4.4 & 6.7 & 19.3 & 35.5 \\
DRM4 & 5.0 & 6.9 & 19.7 & 43.0 \\
\hline
\end{tabular}

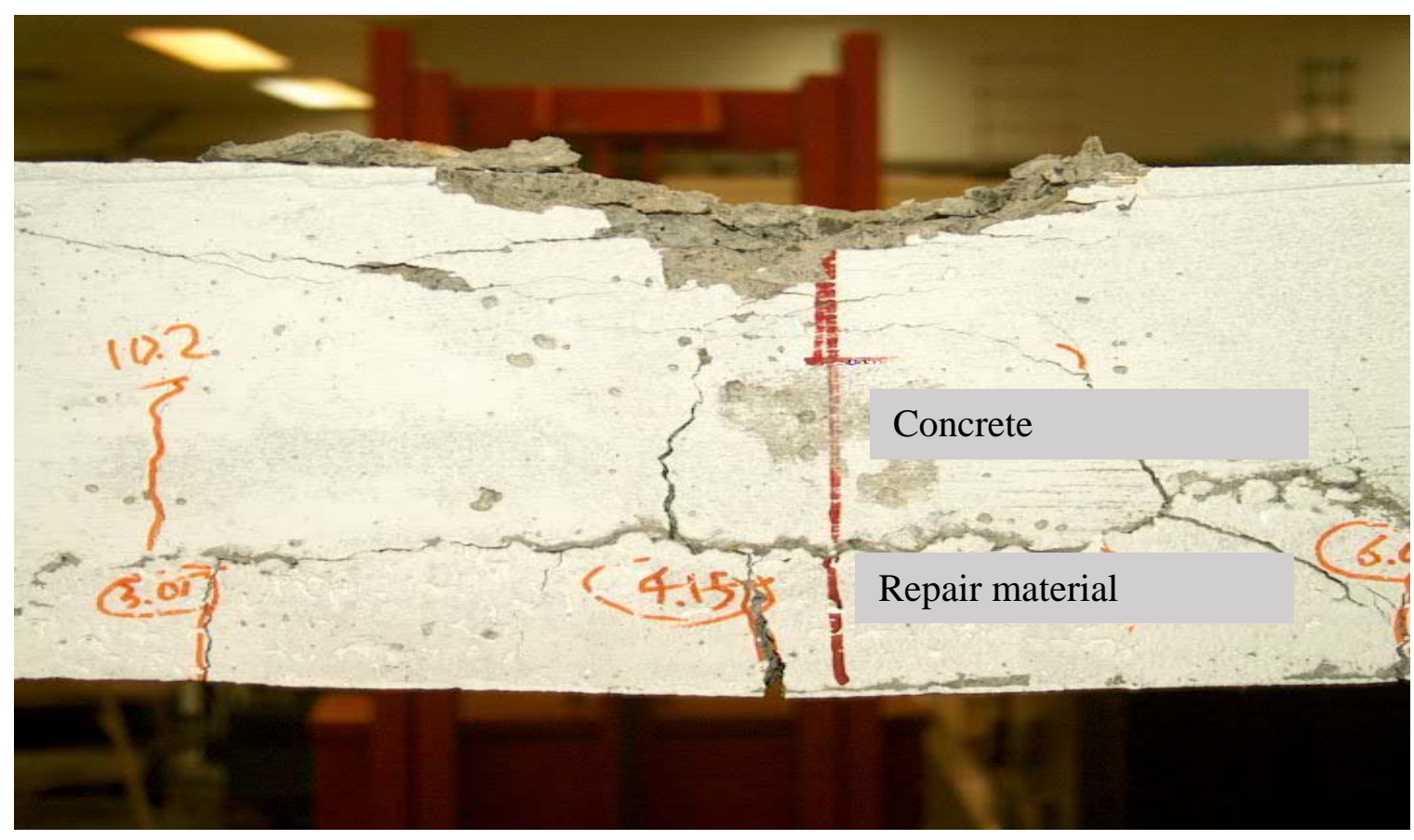

Figure 13. Close up view of the repair material (RM2) at failure.

\section{Conclusion}

This study presented test results on the behavior of patch RMs in plain and reinforced concrete. Four RMs were used and each differed in the mechanical properties of compressive strength, tensile strength and modulus of elasticity. Based on the test results, it can be concluded that:

- Damage in plain concrete reduced the flexural and axial capacity considerably.

- All RMs performed very well in restoring the strength lost due to damage and shared the load with the substrate concrete in flexure and axial compression of plain concrete.
- Compatibility of the mechanical properties between the RM and the substrate concrete is very important. RM4 made with OPC was the nearest in mechanical properties to that of the substrate concrete and hence more compatible. The failure mode of RM4 in slant shear and axial compression was the best among all RMs in terms of adhesion to the substrate concrete at failure, indicating the importance of compatibility between the substrate concrete and the RMs in enhancing the performance of the composite material.

- In reinforced concrete beams, no difference was observed in the behavior of the RMs and all RMs showed good bond till failure. 


\section{References}

Abu-Tair AI (1997), Heat cycling of epoxy mortar repaired beams. ACI Materials Journal 94(2): 129-133.

Al-Farabi S, Kalimur RM, Al-Gahtani A, Hameeduddin M (2006), Behaviour of patch repair of axially loaded reinforced concrete beams. Cement and Concrete Composites 28: 734-741.

American Society for Testing and Materials, ASTM C109. Standard Test Method for Compressive Strength of Hydraulic Cement Mortars.

American Society for Testing and Materials, ASTM C469. Standard Test Method for Static Modulus of Elasticity and Poisson's Ratio of Concrete in Compression.

American Society for Testing and Materials, ASTM C78. Standard Test Method for Flexural Strength of Concrete (Using Simple Beam with Third-Point Loading).

American Society for Testing and Materials, ASTM C882. Standard Test Method for Bond Strength of Epoxy-Resin Systems used with Concrete by Slant Shear.

Al-Zahrani MM, Maslehhuddin M, Ibrahim M (2003) Mechanical properties and durability characteristics of polymer- and cement-based repair materials. Cement and Concrete Research 25: 527-537.

Cabrera JG, Al-Hasan AS (1997), Performance properties of the concrete repair materials. Construction and Building Materials 11(5-6): 283-290.

Courard L, Schwall D, Garbacz A, Piotrowski T (2006), Effect of concrete substrate texture on the adhesion properties of PCC repair mortar. In: Aguiar JB, Jalali S, Camões A, Ferreira R.M. (Eds). Proceedings ISPIC 2006 International Symposium Polymers on Concrete Guimarães, Oficinas Gráficas de Barbosa and Xavier, Lda, Braga, Portugal 99-110.
Courard L, Piotrowski T, Garbacz A (2014), Near-to-surface properties affecting bond strength in concrete repair. Cement and Concrete Composites 46: 73-80.

Garbacz, A., Górka, M., Courard, L., (2005), On the effect of concrete surface treatment on adhesion in repair systems. Magazine of Concrete Research 57(1): 49-60.

Ghassan N, Zai-UL-Hasan C (1999), Reinforced concrete repairs in beams. Construction and Building Materials 1: 195-212.

Liu YP, Wang FZ, Liu MY, Hu SG (2014), A microstructural approach to adherence mechanism of cement and asphalt mortar (CA mortar) to repair materials. Construction and Building Materials 66: 125-131.

Mangat PS, Limbachiya MK (1995), Repair material properties which influence longterm performance of the concrete structure. Construction and Building Materials 11(2): 8190.

Mangat PS, Limbachiya MK (1997), Repair materials properties for effective structural application. Cement and Concrete Research 27(4): 601-617.

Margan DR (1996), Compatibility of concrete repair materials and systems. Construction and Building Materials 10(1): 57-67.

Qian J, You C, Wang Q, Wang H, Jia X, (2014), A method for assessing bond performance of cement-based repair materials. Construction and Building Materials 68: 307-313.

Rio O, Andrade C, Izquierdo D, Alonso C (2005), Behavior of patch-repaired concrete structural elements under increasing static loads to flexural failure. Journal of Materials in Civil Engineering 17: 168-177.

Ueda H, Tamai Y, Kudu T (2011), Evaluation of the durability of cement-based repair materials. Quarterly Report of Railway Technical Research Institute, Japan 52(2): 92-96. 